\title{
Germination Characteristic of Rhizomes of Major Monocotyledonous Weeds in Coconut Plantations of Sri Lanka
}

\author{
S. H. S. Senarathne ${ }^{1}$, D. M. B. M. Bandara ${ }^{2}$ and U. R. Sangakkara ${ }^{2}$
}

\begin{abstract}
Panicum maximum, Panicum repens, Imperata cylindrica, Pennisetum polystachion and Cyperus rotundus are five rhizomatous grass weeds that exist and are problematic in the coconut lands of Sri Lanka. Rhizomatous weeds are the most difficult to control because of their vegetative reproduction by underground propagules. Therefore chemical and biological techniques have failed to control these weeds to acceptable levels. Experiments were conducted to investigate the impact of depth of burial, duration of sun drying or duration of air drying rhizomes of the selected weed species on germination. Depth of burial reduced germination of all species. Burying rhizomes at depths less than $10 \mathrm{~cm}$ inhibited germination of P. maximum and P. polystachion. Burying depths below $30 \sim 40 \mathrm{~cm}$ inhibited germination of all species. Sun drying or air drying rhizomes for durations less than 5 days inhibited germination of $P$. maximum and $P$. polystachion. Germinations of all species were inhibited by sun drying rhizomes for 15 days or air drying rhizomes for 20 days. Sun drying of rhizomes of all species for five days reduced the moisture content to a greater extent than air drying. The results indicated that burying rhizomes at the depthsbelow $30 \sim 40 \mathrm{~cm}$, sun drying rhizomes for durations beyond 15 days or air drying rhizomes for durations beyond 20 days would be effective in controlling germination of these species. The investigations of the experiments also suggest that keeping rhizomes on the soil surface without burying, sun drying rhizomes or air drying rhizomes for durations of $5 \sim 15$ days would produce weak plants.
\end{abstract}

Key words: air drying; depth of burial; germination; rhizomatous weeds; sun drying.

\section{INTRODUCTION}

The growth habit of the coconut palm and canopy structure require a wide spacing between palms to allow abundant sunlight to reach the under storey. Consequently, a wide range of perennial and annual weed species occupy the non utilized space within plantations (Senarathne et al., 2003). Weeds in coconut

\footnotetext{
${ }^{1}$ Coconut Research Institute, Bandirippuwa Estate, Lunuwila 61150, Sri Lanka.

${ }^{2}$ Faculty of Agriculture, University of Peradeniya, Peradeniya 20400, Sri Lanka.

* Corresponding author : Phone)+94-779351163, Fax)+94-312257391, E-mail) shsumith71@yahoo.com
}

(Received August 13, 2012; Examined August 30, 2012; Accepted September 11, 2012)

(C) 2012 Korean Society of Weed Science 
plantations are managed in different ways, under the broad categories of mechanical, chemical and cultural methods (Liyanage and Liyanage 1989). However, eradication of weeds is not expected and weeds have to be managed to some extent so that they do not compete with coconut palm. Slashing either by hand or tractor harrowing, use of herbicides, inter-row cultivation of fast growing leguminous cover crops and grazing by ruminants are currently popular weed control methods. Four wheel tractor mounted slashers and harrows are the main mechanical methods practiced in coconut plantations. Mowing or slashing removes the aerial parts of the weeds, resulting in a depletion of the food supply to the rhizomes (Pethiyagoda 1980). Rhizomatous weeds are the most difficult to control because of their vegetative reproduction by underground propagules (Holt and Orcutt 1996). Panicum maximum, Panicum repens, Imperata cylindrica, Pennisetum polystachion and Cyperus rotundus are five rhizomatous grass weeds that exist and problematic in the coconut plantations (Senarathne et al. 2003). However, rhizomatous weeds emerge at different time periods after application of any kind of control measures. Therefore, a research project was designed to investigate the effects of depth of burial, duration of sun drying or air drying rhizomes of selected rhizomatous weed species on emergence and growth and development after emergence in order to develop a possible and effective mechanical technique for their control.

\section{MATERIALS AND METHODS}

The experiments were carried out in the plant house and laboratory of the Coconut Research Institute located in the Low county Intermediate Zone of the North Western province of Sri Lanka from April to August in 2011. In the plant house, petri dishes and planting trays received photo synthetically active radiation (PAR) ranging from $500 \sim 1150 \mu \mathrm{mol} \mathrm{m}^{-2} \mathrm{~s}^{-1}$ and the average day and night temperature were in the range of $30 \sim 34^{\circ} \mathrm{C}$ and $26 \sim 30^{\circ} \mathrm{C}$ respectively. Relative humidity varied between $35 \sim 60 \%$ during the day and $20 \sim 27 \%$ during the night.

\section{Collection and preparation of rhizomes}

Uniformly grown plants of Panicum maximum, Panicum repens, Imperata cylindrica, Pennisetum polystachion and Cyperus rotundus were uprooted separately from the natural vegetation in coconut plantations. The uprooted weed plants were taken to a shade house and the rhizomes were detached from the mother plants by a sharp knife. The roots of rhizomes were not damaged during the separation. Uniform size rhizomes were cleaned and washed in clean flowing water to remove soil and foreign materials. The rhizomes were dried on paper towels. The fresh weight ranges of each rhizomes batch of each species were measured. The fresh weight ranges of rhizomes of $P$. maximum, $P$. repens, I. cylindrica, $P$. polystachion and $C$. rotundus were 1.5 to $4 \mathrm{~g}, 2$ to $4.5 \mathrm{~g}, 1$ to $2.5 \mathrm{~g}, 2$ to $4.5 \mathrm{~g}$ and 0.3 to $0.6 \mathrm{~g}$, respectively.

\section{Preparation of soils and planting bags}

Soils were collected from a newly cleared land of the CRI to fill the planting bags. Top soil was collected up to a $20 \mathrm{~cm}$ depth. Soils were sieved using a 2 $\mathrm{mm}$ soil sieve to remove rock particles, plant parts and foreign matter. The heights of planting bags varied according to the burying depth of the rhizomes. The planting bags were placed in the plant house.

\section{Experimental design}

The research project included three experiments for the determination of effects of depth of burial, duration of sun drying or air drying rhizomes. All the experiments were conducted as two factor factorials in a Complete Randomized Design (CRD). Different levels of depths and weed species were the two factors of the effect of depth of burial experiment. Different durations of sun drying and weed species were the two factors of the effect of sun drying experiment. Different 
duration of air drying and weed species were the two factors of the effect of air drying experiment. The five weed species were $P$. maximum, $P$. repens, I. cylindrical, $P$. polystachion and $C$. rotundus used and each treatment was replicated five times and a replicate was represented by four planting bags, each bag contained five rhizomes.

\section{Effect of depth of burial on germination of different weed species rhizomes}

The treatments of effect of the depth of burial experiment were formed by combination of five depths and five weed species. The five burying depths were $0,10,20,30$ and $40 \mathrm{~cm}$. Therefore, the rhizomes were planted in 10, 20, 30, 40 and $50 \mathrm{~cm}$ tall planting bags, respectively. The mean soil temperature of planting bags was fluctuated from $34^{\circ} \mathrm{C}$ to $37^{\circ} \mathrm{C}$ during the day and from $28^{\circ} \mathrm{C}$ to $32^{\circ} \mathrm{C}$ during the night inside the plant house on May to August, 2011.

\section{Effect of sun drying on germination of different weed species rhizomes}

The treatments of the effect of sun drying experiments were formed by combination of five levels of sun drying durations and five weed species. The five sun drying durations were $0,5,10,15$ and 20 days. Sun drying was done for $8 \mathrm{~h} /$ day under direct sunlight at an open area. The rhizomes were kept inside the plant house for other $16 \mathrm{~h}$ of a day. The mean air temperature was fluctuated in a range of $25.1^{\circ} \mathrm{C}$ to $29.9^{\circ} \mathrm{C}$ on May to July, 2011. On these months relative humidity of air was fluctuated in a range of $81.5 \%$ to $84.8 \%$ and the sunshine duration was fluctuated from 5.8 to $7.5 \mathrm{~h} \mathrm{day}^{-1}$ (Table 1 ).

\section{Effects of air drying on germination of different weed species rhizomes}

The treatments of the effect of air drying experiment were formed by combination of five levels of air drying durations and five weed species. The five air drying durations were $0,5,10,15$ and 20 days. The air drying was done inside the plant house under photo synthetically active radiation (PAR) ranging from 500 to $1150 \mu \mathrm{mol} \mathrm{m} \mathrm{m}^{-2}$. The mean day and night air temperatures were fluctuated from 30 to $34^{\circ} \mathrm{C}$ and 26 to $30^{\circ} \mathrm{C}$ respectively. The relative humidity was fluctuated from $35 \%$ to $60 \%$ during the day and from $20 \%$ to $27 \%$ during the night inside the plant house on May to August 2011.

In the sun drying or air drying experiments the rhizomes were weighted for fresh weight and dry weights after each drying treatments. The rhizomes were protected from rains during the drying periods. The rhizomes of air drying experiment were not exposed to the direct sun light during the air drying.

\section{Establishment of rhizomes}

The rhizomes of sun drying or air drying experiments were planted in $12 \mathrm{~cm}$ tall planting bags and rhizomes were covered with a $2 \mathrm{~cm}$ deep soil layer. The rhizomes of burying depth, sun drying or air drying experiments were planted in bags after filling

Table 1. Change in rainfall $(\mathrm{mm} / \mathrm{month})$, mean air temperature $\left({ }^{\circ} \mathrm{C}\right)$, relative humidity $(\%)$ of air and mean sunshine duration $\left(\right.$ h day ${ }^{-1}$ ) on May to July 2011.

\begin{tabular}{|c|c|c|c|c|c|c|}
\hline \multirow{2}{*}{ Months } & \multirow{2}{*}{$\begin{array}{c}\text { Rainfall } \\
(\mathrm{mm})\end{array}$} & \multicolumn{2}{|c|}{ Air temperature $\left({ }^{\circ} \mathrm{C}\right)$} & \multicolumn{2}{|c|}{ Relative humidity (\%) } & \multirow{2}{*}{$\begin{array}{l}\text { Sunshine } \\
\text { duration(hr) }\end{array}$} \\
\hline & & am & $\mathrm{pm}$ & am & $\mathrm{pm}$ & \\
\hline May & 110.9 & 26.6 & 29.9 & 84.4 & 81.9 & 7.5 \\
\hline June & 110.4 & 25.1 & 27.2 & 84.8 & 85.4 & 5.8 \\
\hline July & 33.0 & 26.6 & 28.2 & 83.0 & 81.5 & 6.4 \\
\hline
\end{tabular}


the soils up to a $10 \mathrm{~cm}$ depth. The five rhizomes were placed on the filled soils. The depth of the soil layer above the rhizomes was made as same as to the burying depth levels $(0,10,20,30$ and $40 \mathrm{~cm})$ in the burying depth experiment. The planting bags were watered up to field capacity, after the rhizomes were planted. The planting bags were watered at three days intervals up to field capacity and the bags did not received any fertilizer. Weeding was done when other weed plants emerged in the planting bags.

\section{Data Collection and Sampling}

The initial fresh weight ranges of each species were measured in randomly selected 25 rhizomes from each species using an electronic balance. The initial dry weights of each weed species were measured after oven drying for $48 \mathrm{~h}$ at $80^{\circ} \mathrm{C}$. The fresh weights and dry weights after each sun drying or air drying period of each weed species were measured in randomly selected 25 rhizomes batches. Germination percentage of each treatment was measured by counting the number of germinated rhizomes out of the total number of rhizomes. The numbers of days taken to emergence from the planted date of weed plants were counted. Sampling was done as 7 day intervals after emergence of weed plants.

\section{Statistical Analysis}

The model used for statistical analysis was,

$$
\mathrm{Y}_{\mathrm{ij}}=\mu+\tau_{\mathrm{i}}+\mathrm{G}_{\mathrm{ij}}
$$

Where,

$\mathrm{Y}_{\mathrm{ij}}=$ Value for the $\mathrm{i}^{\text {th }}$ treatment from the $\mathrm{j}^{\text {th }}$ replicate

$\mu=$ Sample mean

$\tau_{i}=$ Effect of $i^{\text {th }}$ treatment

$\epsilon_{\mathrm{ij}}=$ Error associated with $\mathrm{Y}_{\mathrm{ij}}$

Since germination percentages and moisture percentages were analyzed, a Generalized Linear Model (GLM) analysis was carried out. The treatment means were compared using Duncan's New Multiple Range Test (DNMRT).

\section{RESULTS AND DISCUSSTION}

\section{Effect of burial depth on germination of selected weed species rhizomes}

Burying at a depth of $10 \mathrm{~cm}$ reduced the germination of rhizomes of $P$. maximum, I. cylindrica, P. polystachion and $C$. rotundus significantly (Table 2 ). In contrast, the germination of the rhizomes of $P$. repens increased when buried at this depth. The study indicated that the rhizomes of $P$. maximum and $P$. polystachion did not germinate unless kept on the soil surface (Table 2). In $P$. repens the germination was highest at $10 \mathrm{~cm}$ depth and declined significantly thereafter (Table 2). In $I$. cylindrica, rhizomes did not germinate at depths beyond $20 \mathrm{~cm}$, and in $C$. rotundus this phenomena was observed only at a depth of $40 \mathrm{~cm}$ (Table 2). The data suggests that burial of rhizomes or pieces of rhizomes of $P$. maximum and P. polystachion will inhibit the

Table 2. Germination percentages of rhizomes of different weed species at different depths of burial.

\begin{tabular}{|c|c|c|c|c|c|}
\hline \multirow{2}{*}{ Burial depth $(\mathrm{cm})$} & \multicolumn{5}{|c|}{ Weed species } \\
\hline & P. maximum & P. repens & I. cylindrica & P. polystachion & C. rotundus \\
\hline 0 & 80 (c) & $80(\mathrm{c})$ & 85 (b) & 75 (d) & 100 (a) \\
\hline 10 & 0 (i) & 100 (a) & 35 (f) & 0 (i) & 80 (c) \\
\hline 20 & 0 (i) & $40(\mathrm{e})$ & 0 (i) & 0 (i) & $25(\mathrm{~g})$ \\
\hline 30 & 0 (i) & 35 (f) & 0 (i) & 0 (i) & $15(\mathrm{~h})$ \\
\hline 40 & 0 (i) & 0 (i) & 0 (i) & 0 (i) & 0 (i) \\
\hline
\end{tabular}

Means followed by the same letter are not significantly different $(\mathrm{P}=0.05$ DNMRT). 
germination. The germination of rhizomes of other species will be inhibited only when buried at depths beyond $30 \sim 40 \mathrm{~cm}$. The rate of decline in germination of rhizomes as affected by the depth of burial was highest in $C$. rotundus followed by $P$. repens, $I$. cylindrica, $P$. maximum and $P$. polystachion, respectively. This rapid decline in $C$. rotundus could be attributed to the very high germination of the rhizomes when placed on the soil surface and the rapid decline with depth of burial.

Species such as $P$. maximum and $P$. polystachion have low rates of germination when buried at a depth of $10 \mathrm{~cm}$. Marambe et al. (1995) reported that no germination was observed when tubers of purple nutsedge (C. rotundus) were buried at depths greater than $40 \mathrm{~cm}$. Hossain et al. (1999) reported that culm emergence from rhizomes of $P$. repens decreased when burial depth was greater than 20 to $30 \mathrm{~cm}$. Chauhan et al. (2006) reported that no seedlings emerged from seeds of rigid ryegrass (Lolium rigidum) when buried at $10 \mathrm{~cm}$.

\section{Effect of sun drying on germination of selected weed species rhizomes}

Sun drying rhizomes for 5 days resulted in a significant reduction in germination of $P$. maximum, $P$. repens, I. cylindrica, $P$. polystachion and $C$. rotundus (Table 3). Rhizomes of P. maximum, I. cylindrica, $P$. polystachion and $C$. rotundus did not germinate when rhizomes were sun dried for durations beyond 5 days.
In contrast germination of $P$. repens declined when rhizomes were sun dried for 5 days or longer and did not germinate when sun drying for 15 days (Table 3). The data suggests that the sun drying of rhizomes or pieces of rhizomes of $P$. maximum, $I$. cylindrica, $P$. polystachion and $C$. rotundus will inhibit germination. The germination of rhizomes of $P$. repens will be inhibited only when sun dried for 15 20 days.

Marambe et al. (1995) reported that sun drying of tubers of purple nutsedge (C. rotundus) for 3 days reduced the tuber germination by $35 \%$. Wills (1987) reported that no doveweed (Murdannia nudiflora) germination was noted when seeds were exposed to constant temperatures of $15^{\circ}, 20^{\circ}, 36^{\circ}$ or $38^{\circ} \mathrm{C}$ for 2 , 4 and 6 days.

\section{Effect of air drying on germination of selected weed species rhizomes}

Air drying rhizomes for 5 days resulted in a significant reduction in germination of $P$. maximum, $P$. repens, I. cylindrica, $P$. polystachion and $C$. rotundus (Table 4). Rhizomes of $P$. maximum and $P$. polystachion did not germinate when air dried for durations beyond 5 days. In I. cylindrica and C. rotundus this phenomenon happened when rhizomes were air dried for durations beyond 10 days. Rhizomes of $P$. repens did not germinate when air dried for 20 days (Table 4).

The data suggest that air drying of rhizomes or pieces of rhizomes of $P$. maximum and $P$. polystachion

Table 3. Germination percentages of rhizomes of different weed species after sun drying for different durations.

\begin{tabular}{cccccr}
\hline \multirow{2}{*}{$\begin{array}{c}\text { Sun drying duration } \\
\text { (days) }\end{array}$} & P. maximum & P. repens & I. cylindrica & P. polystachion & C. rotundus \\
\cline { 2 - 6 } & 85 (b) & 100 (a) & 80 (c) & 80 (c) & 100 (a) \\
\hline 0 & 0 (e) & 80 (c) & 0 (e) & 0 (e) & 0 (e) \\
5 & 0 (e) & 5 (d) & 0 (e) & 0 (e) & 0 (e) \\
10 & $0(\mathrm{e})$ & 0 (e) & 0 (e) & 0 (e) & 0 (e) \\
15 & 0 (e) & 0 (e) & 0 (e) &
\end{tabular}

Means followed by the same letter are not significantly different $(\mathrm{P}=0.05$ DNMRT). 
Table 4. Germination percentages of rhizomes of different weed species after air drying for different durations.

\begin{tabular}{|c|c|c|c|c|c|}
\hline \multirow{2}{*}{$\begin{array}{l}\text { Air drying duration } \\
\text { (days) }\end{array}$} & \multicolumn{5}{|c|}{ Weed species } \\
\hline & $P$. тахітит & P. repens & I. cylindrica & P. polystachion & C. rotundus \\
\hline 0 & 85 (b) & 100 (a) & 80 (c) & 80 (c) & $100(a)$ \\
\hline 5 & 0 (i) & $70(d)$ & $5(\mathrm{~h})$ & 0 (i) & $20(\mathrm{~g})$ \\
\hline 10 & 0 (i) & $65(\mathrm{e})$ & 0 (i) & 0 (i) & 0 (i) \\
\hline 15 & 0 (i) & $30(e)$ & 0 (i) & 0 (i) & 0 (i) \\
\hline 20 & 0 (i) & 0 (i) & 0 (i) & 0 (i) & 0 (i) \\
\hline
\end{tabular}

Means followed by the same letter are not significantly different $(\mathrm{P}=0.05$ DNMRT).

will inhibit germination. Air drying of rhizomes of $I$. cylindrica and $C$. rotundus for durations beyond 10 days will inhibit germination and for $P$. repens the same effect will occur if air dried beyond 20 days. The percentage of decline in germination of rhizomes as affected by the duration of air drying was highest in $P$. repens followed by $C$. rotundus, $P$. maximum, $I$. cylindrica and $P$. polystachion, respectively. This rapid decline in $P$. repens could be attributed to the very high germination of the rhizomes when kept without air drying and decline with the air drying duration. Species such as $I$. cylindrica and $P$. polystachionhave low rates of germination in rhizomes when air dried for 5 days.

\section{Effect of sun dryingon moisture content of different weed species rhizome}

Sun drying for 5 days resulted in a significant reduction in moisture content of $P$. maximum, $P$. repens, I. cylindrica, $P$. polystachion and $C$. rotundus rhizomes
(Table 5). When evaluating the individual species, rhizomes of $P$. maximum, $P$. repens, $I$. cylindrica, $P$. polystachion and $C$. rotundus lost their moisture by $67.94 \%, 30.48 \%, 58.14 \%, 64.85 \%$ and $60.01 \%$, respectively when sun dried for 5 days (Table 5). The data suggests the need to reduce the moisture of $P$. maximum, I. cylindrica, $P$. polystachion and C. rotundus to inhibit germination (Table 3) by 67.94\%, 58.14\%, $64.85 \%$ and $60.01 \%$, respectively. In $P$. repens this phenomena will occur when moisture content is reduced by $41.70 \%$.

The rate of decline in moisture percentage of rhizomes as affected by sun drying was highest in $P$. polystachion followed by $I$. cylindrica, P. maximum, $C$. rotundus, and $P$. repens respectively. This rapid decline in $P$. polystachion could be attributed to the very low moisture content in the rhizomes when sun dried. Out of five weed species moisture retention in rhizomes was highest in P. repens after sun drying for 5, 10, 15 and 20 days. This phenomenon could be associated

Table 5. Moisture percentages (fresh weight basis) of rhizomes of different weed species after sun drying for different durations.

\begin{tabular}{cccccc}
\hline \multirow{2}{*}{$\begin{array}{c}\text { Sun drying duration } \\
\text { (days) }\end{array}$} & P. maximum & P. repens & I. cylindrica & P. polystachion & C. rotundus \\
\cline { 2 - 6 } & 76.35 (a) & 53.86 (a) & 77.22 (a) & 78.37 (a) & 71.37 (a) \\
\hline 0 & 8.41 (b) & 23.38 (b) & 19.08 (b) & 13.52 (b) & 11.36 (b) \\
5 & 7.11 (c) & 21.37 (c) & 11.59 (c) & 10.24 (c) & 10.76 (c) \\
10 & 6.69 (d) & 12.16 (d) & 10.38 (d) & 6.82 (d) & 6.67 (d) \\
15 & 5.87 (e) & 11.45 (e) & 7.23 (e) & 6.15 (e) & 6.02 (e) \\
\hline
\end{tabular}

Means followed by the same letter in a column are not significantly different $(\mathrm{p}=0.05$ DNMRT). 
with high germination percentages of $P$. repens when sun drying was done. Marambe et al. (1995) reported a significant reduction of tuber moisture of purple nutsedge (C. rotundus) when sun dried for 3 days and the tuber lost 50 to $55 \%$ moisture (fresh weight basis) after the first 7 days.

\section{Effect of air drying on moisture content of different weed species rhizome}

Air drying of rhizomes for 5 days resulted in a significant reduction of moisture percentage in rhizomes P. maximum, $P$. repens, I. cylindrica, $P$. polystachion and C. rotundus (Table 6). When evaluating the individual species, the study indicated that the rhizomes of $P$. maximum lost moisture by $34.77 \%$, rhizomes of $P$. repens lost moisture by $24.26 \%$, rhizomes of $I$. cylindrica lost moisture by $51.99 \%$, rhizomes of $P$. polystachion lost moisture by $65.98 \%$ and rhizomes of C. rotundus lost moisture by $33.72 \%$ when air dried for 5 days (Table 6). The need to reduce the moisture of $P$. maximum, $P$. polystachion and $C$. rotundus to inhibit the germination (Table 6) by $34.77 \%, 65.98 \%$, and $51.99 \%$, respectively was seen in this study. In $P$. repens and I. cylindrica this phenomenon will be occur when moisture content is reduced by $40.40 \%$ and $57.76 \%$, respectively.

The rate of decline in moisture percentage of rhizomes as affected by the duration of air drying was highest in P. maximum followed by I. cylindrica, P. polystachion, $C$. rotundus and $P$. repens, respectively. This rapid decline in $P$. maximum could be attributed to the very low moisture content in the rhizomes when sun dried. Out of five weed species moisture retention in rhizomes was the highest in $P$. repens after air drying for $5,10,15$ and 20 days. This phenomenon suggests the high germination percentages of $P$. repens when comparing with the other weed species when air drying was done.

\section{CONCLUSION}

The research program evaluated the impact of different treatments on the germination of rhizomes selected from five weed species. Rhizomes of $P$. maximum and $P$. polystachion germinated only when placed on the soil surface without burying. Burying rhizomes at depths beyond $40 \mathrm{~cm}$ inhibited germination of all species. Sun drying rhizomes of $P$. maximum, $I$. cylindrica, $P$. polystachion and $C$. rotundus inhibited germination. Rhizomes of $P$. repenssun dried up to 15 days and thereafter did not germinate. Air drying rhizomes of $P$. maximum and $P$. polystachion inhibited germination. Air drying rhizomes of $I$. cylindrica and C. rotundus for durations beyond 10 days also inhibited germination. Air drying rhizomes of $P$. repens for durations beyond 20 days inhibited their germination. Sun drying of rhizomes of all species for five days reduced the moisture content to a greater extent than air drying. Reducing moisture content by sun drying of

Table 6. Moisture percentages (fresh weight basis) of rhizomes of different weed species after air drying for different durations.

\begin{tabular}{cccccc}
\hline \multirow{2}{*}{$\begin{array}{c}\text { Air drying duration } \\
\text { (days) }\end{array}$} & P. maximum & P. repens & I. cylindrica & P. polystachion & C. rotundus \\
\cline { 2 - 6 } & 76.35 (a) & 53.86 (a) & 77.22 (a) & 78.37 (a) & 71.37 (a) \\
\hline 0 & 41.58 (b) & 29.60 (b) & 25.23 (b) & 12.39 (b) & 37.65 (b) \\
5 & 27.94 (c) & 21.02 (c) & 19.46 (c) & 9.65 (c) & 21.77 (c) \\
10 & 12.98 (d) & 14.11 (d) & 10.61 (d) & 8.46 (d) & 18.32 (d) \\
15 & 10.65 (e) & 13.46 (e) & 9.31 (e) & 5.76 (e) & 11.90 (e) \\
\hline
\end{tabular}

Means followed by the same letter in a column are not significantly different $(p=0.05$ DNMRT). 
rhizomes of $P$. maximum, $P$. repens, $I$. cylindrica, $P$. polystachion and C. rotundus by $67.94 \%, 41.70 \%$, $58.14 \%, 64.85 \%$ and $60.01 \%$, respectively was sufficient to inhibit germination. When air drying of rhizomes the reduction in moisture content of $P$. maximum, $P$. repens, I. cylindrica, $P$. polystachion and C. rotundus by $34.77 \%, 24.26 \%, 51.99 \%, 65.98 \%$ and $33.72 \%$, respectively was sufficient to inhibit germination. These results suggest that burying and sun or air drying of rhizomes of $P$. maximum, $P$. repens, $I$. cylindrica, $P$. polystachion and $C$. rotundus could reduce germination percentages of rhizomes and their moisture contents.

\section{REFERENCES}

Chauhan, B. S., G. Gurjeet, and C. Preston 2006. Influence of environmental factors on seed germination and seedling emergence of rigid ryegrass (Lolium rigidum). Weed Science 54:1004-1012.

Holt, J. S., and D. R. Orcutt. 1996. Temperature thresholds for bud sprouting in perennial weeds and seed germination in corn. Weed Science 44:523-
533.

Hossain, M. A., Y. Ishimine, H. Akamine, S. Murayama, S. M. M. Uddin, and K. Kuniyoshi. 1999. Effect of burial depth on emergence of Panicum repens. Weed Science 47:651-656.

Liyanage, L. V. K., and M. de. S. Liyanage, 1989. Weed control understory weed management in coconut lands. CORD, 8:48-56.

Marambe, B., U. R. Sangakkara, and S. K. Ratnayaka. 1995 : Control of tuber growth of purple nutsedge (Cyperus rotundus) : Effect of drying and depth of burying : Proceeding of the $15^{\text {th }}$ Asian-Pasific Weed Science Society Conference, 1(B):562-566.

Pethiyagoda, U. 1980. Handbook on Coconut Cultivation. Ceylon Printers Limited, Colombo : 68-70.

Senarathne, S. H. S., A. D. Samarajeewa, and K. C. P. Perera, 2003. Comparison of different weed management systems and their effects on yield of coconut plantations in Sri Lanka. Weed Biology and Management 3:158-161.

Wills, G.D. 1987. Description of purple and yellow nutsedge (Cyperus rotundus and C. esculentus). Weed Technology 1:2-9. 